\title{
FEDERAL POWER TO PROSECUTE VIOLENCE AGAINST MINORITY GROUPS
}

THE gulf between American ideals and social practices is sharply revealed in the recent Report of the President's Committee on Civil Rights. ${ }^{1}$ Perhaps the most serious discrepancy noted by the Committee is the continued use of violence by both private citizens ${ }^{2}$ and public officers ${ }^{3}$ as a weapon for con-

1. Prestentr's Connittree on Civn Rughts, To Secune These Rughis (1947), hereafter referred to as Crv. RTS. REp. The committee was created by Exec. Order No. 9809, 11 FED. REG. 14153 (1946).

2. Civ. RTs. Rep., supra note 1, at 6, 20-4; Fraenker, The Supreure Coukt asto CIVIL LIRERTIES 43 (1937). The announcement of the creation of a Civil Rights Section in the Department of Justice in 1939 brought immediate reports of such violence (sce note 76 infra): "Low class whites' were said to be forcing negroes from their homes. . . . Workers in a southern cigar factory sought protection against the $\mathrm{Ku} \mathrm{Klux} \mathrm{Klan.} \mathrm{.} \mathrm{.}$ Sharecroppers said they were being evicted from the farms they had worked. . . A witness before a Congressional committee reported that he had been assaulted as a result of his testimony. . . . A request was made for an investigation of alleged vigilante activity against labor organizations on the west coast. ..." Schweinhaut, The Ciril Liberlies Section of the Department of Justice, 1 Brr of Rigrts Rev. 206, 207 (1941). The President's Committee on Civil Rights points out that lynching remains a serious threat to civil rights. "The decade from 1936 through 1946 saw at least 43 lynchings. No person received the death penalty, and the majority of the guilty persons were not even prosecuted. . . for seven of the years from 1937 to 1946 . . the coniservative estimates of the Tuskegee Institute show that 226 persons were rescued from threatened lynching. Over 200 of these were Negroes. . ." Crv. RTs. REP., supra note 1, at 23-4.

Other minorities have been attacked. Following the Supreme Court's decision in Minersville School District v. Gobitis, 310 U.S. 586 (1940), "hundreds of attaclss upon the [Jehovah's] Witnesses were reported to the Department of Justice. . . At Kennebunl; Maine, the Kingdom Hall was burned. At Rockville, Afaryland, the police assisted a mob in dispersing a Bible meeting. At Litchfield, Illinois, practically the entire town mobbed a company of some sixty Witnesses. . . . Several Witnesses were charged with riotous conspiracy at Connersville, Indiana, their attorney was mobbed, and he and several other Witnesses who had attended the arraignment were beaten. . . . At Jackson, Mississippi, members of a veterans' organization ... forcibly removed a number of Witnesses and their trailer homes from the town." Rotnem and Folsom, Rccent Restrictions Upon Religious Liberty, 36 Ass. PoL. Scr. Rev. 1053, 1051 (1942). Cf. Catlette v. United States, 132 F.2d 902 (C.C.A. 4th 1943). And Japanese-Americans on the West Coast have been subjected to personal violence. Carr, Federal Protzction of Crvil RIGHTS 17 (1947), and authorities cited therein, id. at $17 \mathrm{n}$. 24; Statement of Japanese American Citizens League, Hearings before Stbcommittee No. 4 of the Commintec on the Judiciary on H.R. 5673, S0th Cong., 2d Sess. 69 (1948).

3. "The frequency with which such cases arise is proof that improper police conduct is still widespread. . . " Crv. RTs. REP., stpra note 1, at 25; testifying before this committee, J. Edgar Hoover referred to a particular jail where "it was seldom that a Negro man or woman was incarcerated who was not given a severe beating, which started off with a pistol whipping and ended with a rubber hose" Id. at 26. Other typical instances have been: allowing trusties physically to attack white juvenile prisoners who had attempted an escape, ibid.; whipping a Negro with a bullwhip and forcing him to jump into a river where he drowned, Crews v. United States, 160 F.2d 746 (C.C.A. 5th 1947); 
trolling Negroes and other minorities through fear.4 Although repression of violence is peculiarly the province of government, local agencies charged with the maintenance of order often fail to provide these groups with adequate protection. 5 Under such circumstances, then, the federal government may well be the only medium through which elimination of the practices reported by the President's Committee can be attempted. ${ }^{\circ}$

beating and kicking a falsely arrested Negro so that he died, Screws v. United States, 325 U.S. 91 (1945); forcing Jehovah's Witnesses to salute the flag and drink quantities of castor oil, Catlette v. United States, 132 F.2d 902 (C.C.A. 4th 1943); branding a Negro boy with a red-hot iron to obtain a confession, United States v. Sutherland, 37 F. Supp. 344 (N.D. Ga. 1940).

4. ". . . lynching is the ultimate threat by which his inferior status is driven home to the Negro. As a terrorist device, it reinforces all the other disabilities placed upon him." Crv. RTs. Rep., supra note 1, at 24; Fraenkel, The Federal Civil Rights Law, 31 Muns. L. REv. 301, 302 (1947); "A lynching is not merely a punishment against an individual but a disciplinary device against the Negro group." MYrpdi, AN AMERTCAN DiLEMrna 561 (1944); ". . . lynching is a symbolic act. . . For every lynching committed there are thousands of threats' of lynching." Constitutional Basis for Federal Anti-Lyncling Legislation, 6 LAw. GuIID REv. 643, 646 (1946). Raper cites many instances of lynchings and violence which he suggests were motivated by a desire to maintain cconomic domination. Raper, The Tragedy of Lynching 36-7, 48-51, 56-8, 73-4, 172-3, 201, 270, 285, $313,317-8,340-2,350-1,466$ (1933). Cf. Cayton and Mitcheld, Black Wonkens ANd the New Unions 439-45 (1939); White, Rope and Faggot 11 (1929).

Compare the broader problem facing the United Nations, discussed in Lemkin, Genocide As A Crine Under International Law, 4 UnITED NATions Buzl. 70 (1948), and an attempted solution in the Genocide Convention adopted by the United Nations, December 11, 1946. Yearbook of the United Nations 254 (1946-7).

5. "In certain states the white population can threaten and do violence to the minority member with little or no fear of legal reprisal." Crv. RTs. REp., stipra note 1, at 29. "Punishment of lynchers is not accepted as the responsibility of state or local governments. .. ." Id. at 23. In the Screws case, 325 U.S. 91 (1945), where a sheriff and his deputies beat a Negro to death without justification, the State of Georgia refuscd to take action.' See note 34, infra. In the Catlette case, 132 F.2d 902 (C.C.A. 4th 1943), where a sheriff led a mob in violence against Jehovah's Witnesses, "state authorities in West Virginia made no effort to punish the persons responsible. . ." CARR, op. cit. supra note 2, at 156. In Pierce v. United States, 146 F.2d 84 (C.C.A. 5th 1914), cert. denicd, 324 U.S. 873 (1945), the defendant had used violence to make girls act as prostitutes, but "both the State and local governments failed to bring Pierce to account." CARR, op. cit. supra note 2, at 118. Cf. J. Edgar Hoover's statement to the President's Committee on Civil Rights: "We have had cases involving civil rights where we had no cooperation from local authorities. In one instance, the sheriff boasted that he intended to talie no action." Crv. RTS. REP., supra note 1, at 124.

Concerning the effectiveness of state civil rights laws, see Konvizz, THE Consrirution AND Civil Rigers 121 and Part 2 (1947); Comment, The New York State Commission Against Discrimination: A Nezw Technique For An Old Prablem, 56 Yale L. J. 837 (1947). See also Bob-lo Excursion Co. v. Michigan, 68 Sup. Ct. 358 (1948), and cases cited therein.

6. The need for effective protection of civil rights is particularly serious in postwar periods. CARR, op. cit. supra note 2 , at 19 . For anti-minority reactions after other wars, see Wecter, When Johnny Comes Marching Home (1944) (anti-Scotch, pp, 24-5; anti-Negro, pp. 135-6, 236-7, 239, 263, 419-24, 426, 551; anti-Irish, p. 237; anti-Jewish, pp. 238, 419, 422-4; anti-Catholic, pp. 423-4). 
The scope of possible national supervision in this sphere, however, is narrowly circumscribed by the constitutional prescription of a federal system under which the primary responsibility for the protection of civil rights has been left with the states. ${ }^{\top}$ Constriction of national action continues to be justified upon several grounds: that governmental power should be widely dispersed among local units to avoid abuse; and that national attempts to solve local problems encounter lack of cooperation and hostility from local authorities, and may weaken local responsibility. ${ }^{8}$

Nevertheless, following ratification of the Fourteenth Amendment after the Civil War, Congress enacted a comprehensive group of statutes designed to guarantee broad rights of national citizenship. ${ }^{\circ}$ Only parts of this program have escaped judicial invalidation, however, and these have been limited by the courts' narrow definition of a "federal right." Since the Slaughterhouse and Civil Rights Cases, ${ }^{10}$ it has been the theory of the Su-

Nor can the serious international effects of a failure to protect minority groups in a time of world crisis be ignored. "The United Stotes is not so strong, the firal triusth of the desnocratic idcal is not so ineritable that we can ignore what the world thinks of us or our record." CIv. RTs. REP., sutpra note 1, at 148; see also 146-7. Cf. Brief for United States, pp. 18-20, MicGhee v. Sipes, Oct. Term 1947, No. 87; Coleman, Freedon from Fear on the Home Front, 29 Iowa L. REv. 415 (1944); Cushman, Our Civil Rights Becone a World Isste, N.Y. Times Magazine Section, January 11, 1948, p. 12; Rotnem, The Federal Civil Right "Not To Be Lynehco", 28 Wasr. U. L. Q. 57 (1943); 1 WOODROW WILSON, WAR AND PEAcE 238-10 (Balier and Dodd ed. 1927).

7. See Slaughterhouse Cases, 16 Wall. 36,76 (U.S. 1872) (State governments were created to establish and secure those "fundamental" privileges, "which belong of right to citizens of all free governments.").

In the civil rights field, it is to be noted that the courts use almost exclusively the loose terminology associated with the doctrine of natural rights implieit in the Constitution. Thus, distinctions which may be connoted by such terms as "right", "privilege", "immunity", "liberty", or "freedom" are frequently blurred and may have no separate significance See Konvrrz, op. cit. supra note 5, at Preface. Similarly, no attempt is made to differentiate "natural rights" supposed to be "inalienable" in all men from "eficetive rights" which the sovereign has either protected in the past or has indieated its willingness to protect in the future. See Hohfeld, Some Fundamental Lcgal Conceptions As Apslicd To Jisdicial Reasoning, 23 YALE L. J. 16 (1913), 26 id. 710 (1917); Lasswell and MIcDougal, Legal Education and Public Policy: Professional Training in the Public Interest, 52 Yale L. J. 203, 265-72 (1943) ; MicDougal and Harer, Property, Wenlti, Ln:id: Alloentron, Planning and Developarent 28 (1948) and authorities cited therein. This discussion explores the gap between the "natural right" and the "efieetive right" to be free from violence.

8. See the statement of then Attorney General Jackson, 1 Bul of Rugres REv. 34, 35-6 (1940) and his dissent in Screws v. United States, 325 U.S. 91, 138 (1945). Contrast President Truman's viewpoint, Crv. RIS. ReP., supra note 1, at vii.

9. The many authorities discussing this program of legislation are collected in CARR and FRAENKEI, op. cit. sitpra note 2; Fraenkel, supra note 4, at 301; and Ko:ivirz, op. cit. supra note 5. And cf. Adamson v. California, 67 Sup. Ct. 1672 (1947) (concerning the meaning of the Fourteenth Amendment as it affects civil rights).

10. Slaughterhouse Cases, 16 Wall. 36 (U.S. 1872) ; Civil Rights Casses, 109 U.S. 3 (1883). The Cizil Rights Cases, id. at 11-7, followed the distinction between the rights of federal and state citizenship made in United States v. Cruikshank, 92 U.S. 542, 543-51 
preme Court that Congress may not, even under the terms of the Fourteenth Amendment, pass "general legislation upon the rights of the citizen"11 except where it "is clothed with direct and plenary powers. . . ."12 Hence "civil rights, such as are guaranteed by the Constitution [solely] against State aggression, cannot be impaired by the wrongful acts of individuals, unsupported by State authority. ..."13

But federal powers enumerated under other sections of the Constitution delimit a number of protected areas which together encompass a limited federal right to be secure from violence where state authorities fail to accord protection. The present discussion seeks to define the extent of these areas and examines possible bases, within the framework of constitutional doctrine, ${ }^{14}$ for more comprehensive federal action to curb violence toward minorities.

\section{General Statutes}

Two general criminal statutes authorizing federal prosecution of civil rights violations survive from the post-Civil War legislation. Section 19 of the Criminal Code ${ }^{15}$ allows federal prosecution where private persons conspire to infringe a right secured to citizens by the Constitution or created thereunder by federal law. Section 20 of the Criminal Code ${ }^{10}$ provides a basis for federal action where one clothed with public authority deprives an inhabitant of such a right; in addition, it protects those rights constitutionally guaranteed against encroachment only by state action. These general laws are supplemented by statutes authorizing federal action against individuals in certain specific situations.

Nevertheless, because of statutory weaknesses and administrative difficulties, federal protection of minorities has been, and is today, haphazard and inadequate.

(1875), and in the Slaughterhouse Cases, supra at 76, based on a dictum in Corfield $v$. Coryell, 6 Fed. Cas. No. 3,230, at 551-2 (C.C.E.D. Pa. 1823).

For further discussion, compare United States v. Powell, 151 Fed. 648 (C.C.N.D. Ala. 1907), with Ex parte Riggins, 134 Fed. 404 (C.C.N.D. Ala. 1904). Cf. United States v. Morris, 125 Fed. 322 (C.C.E.D. Ark. 1903) (right of Negroes to cttlivate land); United States v. Lancaster, 44 Fed. 885 (C.C.W.D. Ga. 1890) (right to be protected from threats against court-declared title). Fraenkel, The Federal Civil Rights Law, 31 MrNN. L. REv. 301, 305-12, 315-6 (1947). And see cases cited in notes 18-29 infra.

11. Civil Rights Cases, 109 U.S. 3, 13 (1883).

12. Id. at 18. See note 7 supra.

13. Civil Rights Cases, 109 U.S. 3,17 (1883).

14. The Attorney General has recently suggested that the doctrine of the Civil Rights Cases, 109 U.S. 3, 13 et seq. (1883), may be "subject to re-examination" by the Supreme Court; "Competent scholars have long questioned the correctness of that ruling". Brief for United States, p. 49, n. 28, Shelley v. Kraemer, U.S. Sup. Ct., Oct. Term 1947, No. 72; Statement of the American Jewish Congress, Hearings before Subcommittec No. 4 of the Connmittee on the Judiciary on H.R. 5673, 80th Cong., $2 \mathrm{~d}$ Sess. 119 (1948).

15. Rev. Stat. $\$ 5508$ (1875), as reenacted, 35 STAT. 1092 (1909), 18 U.S.C. $\$ 51$ (1940).

16. Rev. Stat. $\$ 5510$ (1875), as reenacted, 35 StAT. 1092 (1909), 18 U.S.C. \& 52 (1940). 


\section{Section Ig of the Criminal Code}

Section 19 of the Criminal Code is the only general criminal statute available for federal prosecution of private infringement of civil rights. The statute provides criminal sanctions-imprisonment up to ten years, fines up to $\$ 5000$, and permanent future disability to hold federal office-for participation in any conspiracy "to injure, oppress, threaten, or intimidate any citizen in the free enjoyment of any right or privilege secured to him by the Constitution or laws of the United States."17 But the statute can be used only in a few situations. Since it is a conspiracy statute, it cannot be used to prosecute offenders who act alone. Moreover, it refers to "citizens" and has been held not to offer protection to aliens, even though a treaty with the parent nation provides that they are to enjoy the rights of citizenship. ${ }^{18}$

The principal limitation on the use of the section lies in the application of the Constitutional doctrine restricting the statutory "right" to a "right . . . connected with the powers and duties of the national government."10 Thus, for example, Section 19 does not, according to an early Supreme Court decision, ${ }^{20}$ protect a right to assemble peaceably, but would protect the right to assemble peaceably to petition Congress."1

Nevertheless, the general statutory "right" recognized under Section 19 holds interpretive possibilities which the courts have merely begun to explore. The section has so far been held to extend to cases of interference with voting at federal elections, ${ }^{22}$ intimidation of federal witnesses ${ }^{23}$ and inform-

17. "If two or more persons conspire to injure, oppress, threaten, or intimidate any citizen in the free exercise or enjoyment of any right or privilege secured to him by the Constitution or laws of the United States, or because of his having so exercised the same, or if two or more persons go in disguise on the highway, or on the premises of another, with intent to prevent or hinder his free exercise or enjoyment of any right or privilege so secured, they shall be fined not more than $\$ 5,000$ and imprisoned not more than ten years, and shall, moreover, be thereafter ineligible to any office, or place of honor, profit, or trust created by the Constitution or laws of the United States." 35 STAт. 1092 (1909), 18 U.S.C. $\$ 51$ (1940).

18. Baldwin v. Franks, 120 U.S. 678 (1887). But see Lem Mloon Sing y. United States, 158 U.S. 538, 547 (1895); In re Baldwin, 27 Fed. 187, 191 (C.C. Cal. 1826); In re Impaneling and Instructing the Grand Jury, 26 Fed. 749, 754 (D. Ore. 1886).

19. United States v. Cruikshank, 92 U.S. 542, 552 (1875). ". . . every right created by, arising under or dependent upon the Constitution of the United States may be protected and enforced by Congress, by such means and in such manner as Congress, in the exercise of the correlative duty of protection, or of the legislative powers conferred upon it by the Constitution, may in its discretion deem most eligible and best adapted to attain the object." Logan v. United States, 144 U.S. 263, 293 (1892) (discussing all the earlier cases). See pp. 857-8 supra.

20. United States v. Cruikshank, 92 U.S. 542 (1875).

21. Id. at 552 .

22. United States v. Saylor, 322 U.S. 385 (1944) ; United States v. Classic, 313 U.S. 299 (1941) ; United States v. Mosley, 238 U.S. 383 (1915); Wiley v. Sinkler, 179 U.S. 58 (1900); Ex parte Yarbrough, 110 U.S. 651 (1884); United States v. Aczel, 219 Fed. 917 (D. Ind. 1915), aff'd, 232 Fed. 652 (C.C.A. 7th 1916); Felix v. United States, 185 Fed. 685 (C.C.A. 5th 1911). See also Rotnem, Clarification of the Ciril Rights Statutes, 2 BIIL of RIGHTS REv. 252 (1942).

23. Foss v. United States, 266 Fed. 881 (C.C.A. 9th 1920). Contra: United Stztes v. Sanges, 48 Fed. 78 (C.C.N.D. Ga. 1891). 
.ers, ${ }^{24}$ and violence against federal officers ${ }^{25}$ and persons in their custody. ${ }^{20}$ And in Powe v. United States, ${ }^{27}$ decided in 1940, although a newspaper editor's right to discuss local matters was held not to be a federal right, it was indicated that there is a federal right to discuss federal matters.

Section 19 has been useful, furthermore, in providing criminal sanctions for federal laws lacking penal provisions, such as the Homestead Act, granting rights to make a homestead entry on public lands, ${ }^{28}$ and the National Labor Relations Act. ${ }^{29}$ Since these statutes establish federal rights, prosecutions may be brought under Section 19 against those who seek to deprive a person of their benefits.

But, limited in its application by its phraseology and the present status of court interpretation, Section 19 "is not the powerful weapon needed to combat the serious situation which exists in the civil rights field today." 30

\section{Section 20 of the Criminal Code}

Section 20 of the Criminal Code makes it a misdemeanor for anyone, "under color of any law, statute, ordinance, regulation, or custom, willfully" to deprive "any inhabitant" of a federally secured right, or to subject him to different punishments because of alienage, race, or color. ${ }^{31}$ Although Section 20 is broader than Section 19 in that it is not a conspiracy statute, and protects all "inhabitants" rather than just citizens, it had been used in only

24. Motes v. United States, 178 U.S. 458 (1900); In re Quarles and Butler, 158 U.S. 532 (1895) ; Nicholson v. United States, 79 F.2d 387 (C.C.A. 8th 1935).

25. United States v. Davis, 103 Fed. 457 (C.C.W.D. Tenn. 1900); United States v. Patrick, 54 Fed. 338 (C.C.M.D. Tenn. 1893).

26. Logan v. United States, 144 U.S. 263 (1892). Thus Section 19 covers some lynching situations. For other cases extending the concept of a federal right, see note 10 supra.

27. 109 F.2d 147 (C.C.A. 5th 1940), cert. denied, 309 U.S. 679 (1940). "Because the federal government is a republican one in which the will of the people ought to prevail, and because that will ought to be expressive of an informed public opinion, the frecdom of speaking and printing on subjects relating to that government, its elections, its laws, its operations and its officers is vital to it." Id. at 151.

28. Rev. Stat. \$2289 (1875), 43 U.S.C. \$161 (1940). United States v. Waddell, 112 U.S. 76 (1884) ; Nixon v. United States, 289 Fed. 177 (C.C.A. 9th 1923).

29. 49 Stat. $\$ \$ 449-57$ (1935), 29 U.S.C. $\$ \$ 157-66$ (1940); United States v. Mary Helen Coal Co., unreported (C.C. Ky. 1938); CARR, op. cit. supra note 2, at 27 n.38, also 185-8; Department of Justice Circular No. 3673, April 8, 1942.

30. Clark, A Federal Prosecutor Looks at the Civil Rights Statutes, 47 CoL. L. REv. 175, 181 (1947) ; Civil Rights; The Boundless Responsibility of Lazeycrs, 32 A.B.A.J. $453(1946)$.

31. "Whoever, under color of any law, statute, ordinance, regulation, or clistom, willfully subjects, or causes to be subjected, any inhabitant of any State, Territory, or District to the deprivation of any rights, privileges, or immunities secured or protected by the Constitution and laws of the United States, or to different punishments, pains or penalties, on account of such inhabitant being an alien, or by reason of his color, or race, than are prescribed for the punishment of citizens, shall be fined not more than $\$ 1,000$, or imprisoned not more than one year, or both." 35 SтAт. 1092 (1909), 18 U.S.C. $\$ 52$ (1940). 
two reported cases before 1939.32 Since that time it has received a thorough examination in Screws $v$. United States. ${ }^{33}$ A Georgia sheriff, angered when a Negro engaged counsel to recover a pistol seized from him by the sheriff, arrested the Negro and, without justification, beat and kicked him to death. After the Justice Department's "strenuous efforts" to persuade Georgia to act had failed, ${ }^{34}$ the United States Attorney General initiated prosecution. ${ }^{35}$ Indictments were obtained from a federal grand jury, the defendants were convicted, $^{36}$ and the Circuit Court of Appeals affirmed the conviction. ${ }^{37} \mathrm{On}$ appeal to the Supreme Court, four justices felt that Section 20 could be held constitutional against the charge of vagueness only if the jury were properly instructed on the element of "wilfulness." 38 Since this instruction had not been given, the case was sent back for a new trial. Justices Frankfurter, Roberts, and Jackson dissented on the ground that Section 20 was confined to "attempted deprivations of federal rights by State lav"30 and did not cover breaches thereof by state officials, so that the defendant's act was not done "under color" of state law; and also that the entire statute failed to meet the standard of definiteness required in criminal statutes. Justices Murphy and Rutledge felt the conviction should be sustained, the former arguing that however invalid other applications of Section 20 might be, it was properly used in this situation, where questions of "vagueness" and "lack of warning" to the defendants were scarcely applicable considering the nature of the crime. ${ }^{40}$

32. United States v. Stone, 188 Fed. 836 (D. 11d. 1911); United States v. Buntin, 10 Fed. 730 (C.C.S.D. Ohio 1882).

33. 325 U.S. 91 (1945), 55 YALE L. J. 576 (1946); Carr, Serequs 2. United Stoles, 31 CoRs. L. Q. 48 (1945); Cohen, The Screws Case: Federal Protection of Negro Rights, 46 COL. L. REv. 94 (1946); Coleman, supra note 6, at 423-4.

34. The local authorities "felt helpless in the matter" because of the necessity of relying on the accused himself to gather the evidence. And for the state's attorney to seel: an indictment involved a complicated process which could be blocked at the county level. Brief for United States, p. 50, Screws v. United States, 325 U.S. 91 (1945); Cann, op. cit. supra note 2, at 107; Note, 55 Y ALE L. J. 576, 583, and n. 64 (1946). The dissenters, nevertheless, criticized the federal government's prosecution: "Instead of leaving this misdeed to vindication by Georgia law, the United States deflected Georgia's responsibility by instituting a federal prosecution." Screws v. United States, 325 U.S. 91, 138 (1945).

35. "The Department of Justice has established a policy of strict self-limitation with regard to prosecutions under the civil rights acts. When violations of such statutes are reported, the Department requires that efforts be made to encourage state officials to tal:e appropriate action under state law." Brief for the Government, Id. at 4S-9.

36. See CARR, op. cit. stipra note 2 , at 133-46.

37. 140 F.2d 662 (C.C.A. 5th 1944).

38. 325 U.S. 91, 92-113 (1945). Justice Rutledge voted with this group to malie possible a disposition of the case.

Theoretically, the requirement would be equally applicable to prosecutions under Section 19, although there are no cases which have so held. But cf. note 81 infro.

39. Id. at 143. See note 8 supra.

40. Id. at 134-8. See International Harvester Co. v. Kentuchy, 234 U.S. 216, 221-4 
The case settled the constitutionality of Section 20, and established under "color" of law as meaning that the section applied to state officials acting under "pretense" of law,"1 but the Court's requirement that "wilfulness" be tested by a "specific intent to deprive a person of a federal right made definite by decision or other law . . ."42 suggested a road of escape to miscreants. The requirement would seem to limit the applicability of Section 20 not merely to rights implicitly protected by the Constitution against state infringement, but to rights made explicit by its language, or already spelled out in decision or statute. ${ }^{43}$ Thus, an offender who could persuade the jury that he intended only a simple assault would avoid federal penalties. As a result, subsequent prosecutions may be impeded. ${ }^{44}$

In lynching situations, Section 20 is useful only where a public officer is involved. It might be used (1) where a public officer conspires with a mob to lynch, or actively assists a mob in lynching; (2) where a posse, deputized

(1914), where the vagueness test was first announced by the Supreme Court; Note, 55 Yale L. J. 576, 580 and n. 36 (1946); Note, 45 HARv. L. Rev. 160 (1931).

Compare Mr. Justice Murphy's dissent in United States v. Gaskin, 320 U.S. 527, 530 (1944), with his opinion herein; also note the individual philosophies of the Justices expressed in United States v. Saylor, 322 U.S. 385 (1944), and United States v. Classic, 313 U.S. 299 (1941).

41. 325 U.S. 91, 111 (1945) ; United States v. Classic, 313 U.S. 299, 326 (1941); Burt v. City of New York, 156 F.2d 791, 792 (C.C.A. 2d 1946); Catlette v. United States, 132 F.2d 902, 905-6 (C.C.A. 4th 1943). See also Fraenkel, supra note 4, at 320-1.

42. 325 U.S. 91,103 (1945).

43. The Attorney General has interpreted the requirement: The accused "must have at the time he commits the offense the clear purpose of depriving his victim of a specific federal right, i.e., a right which has been made specific either by the express terms of the Constitution or laws of the United States, or by decisions interpreting them." Clark, $A$ Federal Prosecutor Looks at the Civil Rights Statutes, 47 CoL. L. REv. 175, 182 (1947).

Mr. Justice Rutledge, concurring in Screws v. United States, 325 U.S. 91, 113 (1945), construed the requirement less strictly than the Court: "Generally state officials know something of the individual's basic legal rights. If they do not, they should, for they assume that duty.... If their knowledge is not comprehensive, state officials know or should know when they pass the limits of their authority, so far at any rate that their action exceeds honest error of judgment and amounts to abuse ... their sworn oath and their first duty are to uphold the Constitution, then only the law of the state. . . . Since the statute [Section 20] . . condemns only something more than error of judgment . . . officials who violate it must act in intentional or reckless disregard of individual rights and cannot be ignorant that they do great wrong. . . ." Id. at 129-30.

44. On retrial of the Screzus case, the defendants were acquitted. The local United States Attorney reported that the judge's charge, based on the Supreme Court's interpretation of wilfulness, was very damaging to the Government's case. CaRR, op. cit. supra note 2 , at 115; Clark, supra note 43, at 182; Crv. RTs. ReP., supra note 1 , at 157.

At least one prosecution since the Screzws case, however, has succeeded notwithstanding this difficulty. Compare the discussion of wilfulness in Crews v. United States, 160 F.2d 746 (C.C.A. 5th 1947), affirming a conviction under Section 20, "If . . an officer vents his malice upon a prisoner and deprives him of a constitutional right, this manifestation and use of personal spleen need not necessarily negative the fact that such officer might at the same time have also acted with the conscious and wilful purpose of depriving the prisoner of constitutional rights." Id. at 749-50. 
or led by a public officer, kills a person without justification ; $^{45}$ or (3) against private persons participating in a lynching with an official liable under Section 20 , by combining Section 20 with the general conspiracy statute or with the statute defining principals to a conspiracy. ${ }^{10}$ This combination might be necessary in a situation where the victim is not a citizen, or was seized from state custody, and the private persons involved could not be prosecuted under Section 19. Such a combination of Section 20 and the general conspiracy statute has been successfully employed to prosecute a sheriff, a jail trusty, and a lawyer guilty of collaborating to maintain a "kangaroo" court, where money was extorted by force from persons improperly arrested and held. ${ }^{47}$

Since violation of Section 20 is a misdemeanor, it is possible to employ a criminal information ${ }^{48}$ when a grand jury refuses to return an indictment because of local hostility to the prosecution, and significant convictions have been secured by this method. ${ }^{49}$

\section{Criminal Sanctions}

\section{Special Statutes}

In addition to the actions possible under these statutes, the federal government may also prosecute private persons or public officials in a fev specific statutory situations.

It is a misdemeanor under the Hatch Political Activity Act to "intimidate, threaten, or coerce, or to attempt to intimidate, threaten, or coerce" any voter at a federal election. ${ }^{50}$ Protection of the Hatch Act has, however, been held not to extend to primaries since a provision for such coverage was eliminated from the original bill. ${ }^{51}$ Another provision of the Act makes it a misdemeanor to "deprive, or attempt to deprive, or threaten to deprive" a person of federal relief or work benefits because of race, color, creed, or political activity." The substantially similar Section 30 of the Emergency Relief Appropriations Act of $1939^{53}$ has been used in connection with a primary election at which

45. United States v. Trierweiler, 52 F. Supp. 4 (E.D. IIl. 1943).

46. 35 Stat. 1096 (1909), 18 U.S.C. $\$ 88$ (1940); 35 StAT. 1152 (1909), 18 U.S.C. $\S 550(1940)$.

47. Culp v. United States, 131 F.2d 93 (C.C.A. Sth 1942).

48. 46 StAT. 1029 (1930), 18 U.S.C. § 541 (1940).

49. Catlette v. United States, 132 F.2d 902 (C.C.A. 4th 1943); United States v. Buchanan, unreported, Department of Justice Case No. 144-14-1 (1943); United States v. Erskine, unreported, Department of Justice Case No. 144-68-9 (1943); Cans, op. cit. supra note 2, at 159-60, 185-6; Coleman, stpra note 6, at 423-4.

50. 53 SтAт. 1147 (1939), 18 U.S.C. $\$ 61$ (1940).

51. United States v. Malphurs, 41 F. Supp. 817 (S.D. Fla. 1941). See Mir. Justice Douglas, dissenting in United States v. Classic, 313 U.S. 299, 337-9 (1941). The Civil Rights Section of the Department of Justice has been criticized for its failure to attempt further utilization of this section of the Hatch Act. CARR, op. cit. sispra note 2, at 178-9.

52. 53 StAT. 1147 (1939), 18 U.S.C. $\$ 61$ (c) (1940).

53. 53 Stat. 927,937 (1939), 15 U.S.C.A. \$\$ 721-728 (Supp. 1947). 
candidates for federal office were nominated, ${ }^{\text {t4 }}$ and to prosecute persons responsible for violent picketing of a WPA project. ${ }^{55}$

Intimidation of a federal witness-any witness before a federal court or commissioner, or a federal investigative or administrative committee or agency -is a misdemeanor under Sections 135 and 135 (a) of the Criminal Code.00 The protection offered by these sections has been extended to include pro. spective witnesses before such agencies. ${ }^{57}$

Enacted under the more inclusive terms of the Thirteenth Amendment, ${ }^{58}$ the federal criminal statute prohibiting peonage ${ }^{60}$ - "a status or condition of compulsory service, based upon a real or alleged indebtedness of the peon to the master" 60 _has been liberally construed by the courts. ${ }^{\text {"1 }}$ During the last few years, the Act has been successfully used to prosecute a variety of forms of involuntary servitude. ${ }^{62}$ In situations where no debt is involved, but the laborer is compelled by force or threats of force to remain at work, the prosecution may be brought under the ancient Slave Kidnapping $A c t,{ }^{03}$ or one

54. United States v. Malphurs, 46 F. Supp. 903 (S.D. Fla. 1942).

55. Unreported. Schweinhaut, sitpra note 2, at 208. An attempt was made to apply it in Alabama against a Farm Security Administration supervisor who allegedly tried to force certain Negroes to give up the benefits of a farm security loan. Ibid.

56. 59 SтAт. 234 (1945), 18 U.S.C. $\$ \$ 241,241$ (a) (Supp. 1946).

57. "If he knows or is supposed to know material facts, and is expected to testify to them, or be called on to testify, he is a witness." Odom v. United States, 116 F.2d 996, 998 (C.C.A. 5th 1941), res'd on other grounds, 313 U.S. 544 (1941).

58. "Neither slavery nor involuntary servitude, except as punishment for crime whereof the party shall have been duly convicted, shall exist within the United States, or any place subject to their jurisdiction.

"Congress shall have power to enforce this article by appropriate legislation." U.S. Const. Amend. XIII.

59. "Whoever holds, arrests, returns, or causes to be held, arrested, or returncd, or in any manner aids in the arrest or return of any person to a condition of peonage, shall be fined not more than $\$ 5,000$, or imprisoned not more than five years, or both." REv. STAT. §5526 (1875), 18 U.S.C. § 444 (1940).

60. Bailey v. Alabama, 219 U.S. 219, 242-3 (1911); Clyatt v. United States, 197 U.S. 207,215 (1905).

61. United States v. Gaskin, 320 U.S. 527 (1944); Peonage Cases, 123 Fed. 671 (M.D. Ala. 1903).

62. United States v. Gaskin, 320 U.S. 527 (1944) ; Pierce v. United States, 146 F.2d 84 (C.C.A. 5th 1944), cert. denied, 324 U.S. 873 (1945); United States v. Johnson, unreported, Department of Justice Case No. 50-17-9 (1944). CarR, op. cit. supra note 2, at 180-2. Department of Justice Circular No. 3591, December 12, 1941. Peonage offenses are not uncommon today. CIv. RTs. REP., supra note 1, at 29-30. For a curious survival of the outmoded notion that the debt be evidenced by an express contract, see dissenting opinion in Pierce v. United States, supra at 86.

63. "Whover kidnaps or carries away any other person, with the intent that such other person be sold into involuntary servitude, or held as a slave; or who entices, persundes, or induces any other person to go on board any vessel or to any other place with the intent that he may be made or held as a slave, or sent out of the country to be so made or held; or who in any way knowingly aids in causing any other person to be held, sold, or carried away to be held or sold as a slave, shall be fined not more than $\$ 5,000$, or im- 
of the general criminal statutes discussed above.

\section{Civil Remedies}

Supplementing available criminal penalties, federal statutes grant injured persons a civil suit for redress in the federal courts, ${ }^{05}$ but these laws have proved ineffective to protect minority groups from violence because the right has been limited to a cause of action against a public official who infringes a federally guaranteed right. ${ }^{6 B}$ It has been suggested that the civil remedy be combined with a system of bonding public officers. ${ }^{67}$ But granting the desirability of the reform, civil remedies would still be inadequate, because the victims of these deprivations ordinarily lack funds ${ }^{68}$ to maintain a prosecution, and the standing in the community to arouse support. ${ }^{60}$

prisoned not more than five years, or both." REv. STAT. $\$ 5525$ (1875), 18 U.S.C. $\$ 443$ (1940). United States v. Ingalls, 73 F. Supp. 76 (S.D. Cal. 1947); United States v. Skrobarscek, unreported, Department of Justice Case No. 50-74-6; Cans, op. cil. sispra note 2, at 182; Folsom, A Slave Trade Law in a Contemporary Selting, 29 Cons. L. Q. 203 (1943).

64. See pp. 858-63 supra. Smith v. United States, 157 Fed. 721 (C.C.A. Sth 1907) (under Section 19 of the Criminal Code). Contra: United States v. Eberhart, 127 Fed. 254 (C.C.N.D. Ga. 1899) (indictment alleging defendants forced victim to sign contract for work; no federal offense stated).

65. Rev. Stat. \$1979 (1875), \& U.S.C. \$43 (1940); Rev. StAt. \$1980 (1875), \& U.S.C. $\$ 47$ (1940); REv. STAT. \$1981 (1875), \& U.S.C. \$48 (1940).

66. See Snowden v. Hughes, 321 U.S. 1, 13 (19.44); Hague v. C.I.O., 307 U.S. 496, 509-11 (1939) ; Bomar v. Bogart, 159 F.2d 338, 339 (C.C.A. 2d 1947); Picling v. Pennsylvania R.R., 151 F.2d 240, 248-50 (C.C.A. 3d 1945); Love v. Chandler, 124 F.2d 785, 786 (C.C.A. Sth 1942) ; Allan v. Corsano, 56 F. Supp. 169, 171-2 (D. Del. 1944). The victims in Catlette v. United States, 132 F.2d 902 (C.C.A. Ath 1943), brought suits resulting in a compromise settlement of $\$ 52.28$ to each victim. CARR, op. cit. sipra note 2 , at 157 .

Nevertheless, many suits have been brought against public officers for various forms of non-violent discrimination. These have been useful in expanding the concept of state action. See pp. 871-2 infra. Election matters: Smith v. Allwright, 321 U.S. 649 (1944) (party convention resolution excluding Negroes from party primaries held state action); Chapman v. King, 154 F.2d 460 (C.C.A. 5th 1946), cert. denied, 327 U.S. 800 (1946) (damages recoverable against local party authorities who deny Negro right to vote in a federal primary election). But cf. Mfitchell v. Wright, 62 F. Supp. 580 (AID. Ala. 1945) (unsuccessful class action for Negroes denied right to vote). Discrimination in teachers' salaries: Alston v. Norfolk, 112 F.2d 992 (C.C.A. 4th 1940), cert. denied, 311 U.S. 693 (1940) (Negro teachers entitled to injunction against discrimination in salary rates). Discrimination in librarian sclection: Kerr v. Enoch Pratt Free Library, 149 F.2d 212 (C.C.A. 4th 1945), cert. denied, 326 U.S. 721 (1945) (denial to Negress of opportunity to train as librarian by private governing board of library supported with city funds held state action). In Refoule v. Ellis $c t$ al., $74 \mathrm{~F}$. Supp. 336 (N.D. Ga. 1947), a preliminary injunction was granted a French citizen to restrain police officers from improperly taking him into custody on suspicion of uxoricide.

67. Recommendation of Circuit Judge Jerome Frank in his seminar in Fact Finding at Yale Law School, November, 1947.

68. CIV. RTS. REP., supra note 1, at 25; CARR, op. cit. supra note 2, at 21-2.

69. Arthur T. Vanderbilt, Chief Justice designate of the New Jersey Supreme Court, and Past President of the American Bar Ass'n, has described the situation: "The in- 


\section{Possible Bases for Increased Faderal Supervision}

Beyond the present reach of federal authority, there lies a "no-man's" land where violence or threatened violence may continue uninhibited by effective societal sanctions. ${ }^{70}$ Unless the violation falls within the limited area covered by special statutes, private non-conspiratorial acts of aggression toward minorities are immune from federal prosecution. Nor, even when there is evidence of conspiracy, may federal power be exercised against lynchers who seize their victim from blameless state officials, ${ }^{71}$ or against vigilantes who drive "radicals" out of their homes and deport them from the state, 72 or who use violence to force Negroes out of their jobs. ${ }^{73}$

Nevertheless, without disturbing the organic pattern of the federal system, a more vigorous federal enforcement program to realize the full potentialities of present laws, combined with statutory amendment and broader court interpretation, can considerably enlarge the protection of minorities.

\section{Administrative Reform}

In the enforcement field, the Justice Department faces peculiarly difficult problems arising out of strong local hostility in many parts of the country. ${ }^{74}$ Moreover, the Civil Rights Section in the Department ${ }^{75}$ must at present carry on its activities with an inadequate staff and no investigative force under its control. As a result, although deluged with complaints since its establishment in 1939 by the then Attorney General (now Mr. Justice Murphy), it has prosecuted but a tiny fraction of the many thousands received, and has obtained convictions in a lesser number. ${ }^{70}$

dividual whose constitutional rights are assailed is generally a member of an unpopular minority. ... The lawyer who essays to aid an unpopular cause is subject to peculiar social pressures. His old and valued clients are likely to intimate to him ... that he might better devote his energies to their own vastly more important affairs. Does he not fear, they quietly insinuate, that by sponsoring strange causes he may lose [his] reputation for sober judgment and social soundness. . . " 1 BiLl of Rights REv. 42 (1940).

70. See Clark, A Federal Prosecutor Looks at the Civil Rights Statuecs, 47 Col. L. REv. 175, 181 (1947).

71. United States v. Powell, 151 Fed. 648 (C.C.N.D. Ala. 1907). See Rotnem, supra note 6 , at $67-8$.

72. United States v. Wheeler, 245 U.S. 281 (1920). The validity of the holding is doubted today. Meyers, Federal Privileges and Immunities: Applied to Ingress and Egress, 29 CORN. L. Q. 489 (1944); CARR, op. cit. supra note 2, at 188-9.

73. Hodges v. United States, 203 U.S. 1 (1906). The power of the federal government in respect to protection of jobs is increased by the federal rights created under the National Labor Relations Act. See note 29 supra.

74. These problems are examined in detail in CARR, op. cit. supra note 2.

75. A detailed history and analysis of the Civil Rights Section is found in the study made by the former Executive Secretary of the President's Committee on Civil Rights, CARR, op. cit. supra note 2.

76. While it is commonly asserted that the Civil Rights Section has received nearly seventy thousand complaints during its existence this number in fact represents all mall 
To dissipate the ignorance and lack of concern which surrounds the problem of the protection of minority rights, ${ }^{77}$ Congress could establish a permanent version of the President's Committee on Civil Rights to further national education. In addition, Congress could see that the Justice Department Civil Rights Section is no longer hampered by lack of personnel and funds. ${ }^{78}$ For, although the Section suffers from the laxity and submission to local pressure on the part of United States Attorneys in many parts of the country,70 its comparatively few prosecutions have had beneficial effects sufficient to recommend a continuance and enlargement of its work. 80 Expansion of the Section and its activities would seem particularly important, if statutory reform to broaden the base of rights federally protected is to be considered.

\section{Statutory Amendinent}

In its Report, the President's Committee recommended legislation amending Section 19 and supplementing Section 20. Appreciating that the content of Section 19 must depend largely upon the extent to which the courts will recognize a federal right to be free from private aggression, the Committee did

received by the Section. About thirteen thousand complaints have been concerned with possible invasions of federal rights. Up to January 1, 1947, the Civil Rights Section had instituted action in 178 cases, obtaining 101 convictions, and convicting 130 defendants. Clark, A Federal Prosecutor Looks at the Civil Rights Stalutc, 47 Cor L. Rev. 175, 181 (1947) ; CARR, op. cit. supra note 2, at 125-33; for the Department of Justice policy of strict self-limitation, see note 35 stpro.

77. ". . . there is a very great and urgent need for a national program of eduestion that the man on the street be made to realize that every attack upon the constitutional rights of others ... weakens the fabric of the Constitution itself. Such a program should commend itself to the organized bar of the country, and if this nation cannot afford martyrs and the followers they inspire, the lawyer should accept, willingly and carnestly, his share in that educational effort." Schweinhaut, supra note 2, at 216; Clark, Ciril Rights:The Boundless Responsibility of Lawyers, 32 A.B.A.J. 453, 457 (1946).

78. "At no time since its creation has the Civil Rights Section occupied more than four or five modest office rooms in the Justice Department building, or had more than eight or ten lawyers and professional workers on its staff, assisted by three or four clerks and stenographers." CARR, op. cit. supra note 2 , at 122 . See recommendations in Civ. RTs. REP., stpra note 1, at 151-5.

79. CARR, op. cit. supra note 2 , at $133-46$.

80. After an acquittal in a police brutality case, the United States Attorncy wrote to the Attorney General: "The defendants are at liberty, but it is my humble opinion that the prosecution will do good for years to come. None of these state officers likics to be hauled into Federal Court. ..." Crv. RTs. REP., stpra note 1, at 128-9. Aitter an acquittal in a lynching case, an attorney who had served as a special assistant wrote: "The trial of the case impressed officers from the Governor down to the Constables with the importance of an officer according to a prisoner the highest degree of protection." Ibid." After a lynching indictment, the Attorney General of Mfississippi was claimed to have ". . . stated to me that in his judgment the indictment will have a fine moral effect in Mississippi. . . ." CARR, op. cit. supra note 2, at 145. "The conviction received favorable notice in many Southern papers and there seems little doubt that this case ... has been effective in breaking up at least the direct practice of peonage." Id. at 181. 
not attempt to enumerate more specifically the offenses subject to its penalty. ${ }^{81}$ Instead, the Committee confined its recommendations to changes in the conspiracy and penalty provisions of the statute. It proposed: (1) that federal prosecution be extended thereunder to private individual offenders; 82 and (2) that the provision which prohibits anyone convicted under the Section from holding any federal office be eliminated. ${ }^{83}$ It has been shown that this provision is a serious deterrent to convictions, and does not add sufficient strength to the law to warrant its retention. 84 In addition to these recommended revisions, other changes may be desirable. At the present time, only federal rights of "citizens" are protected against private infringement; the protection might well be extended to all "inhabitants." Inclusion within the statute's coverage of all rights guaranteed by "treaties" of the United States would further ensure aliens' rights, and reinforce the argument that these laws must be viewed in the light of the United Nations Charter. ${ }^{85}$

The considerations which restrain a more precise delineation of offenses punishable under Section 19 are absent in the case of aggression by public officers. ${ }^{86}$ To supplement Section 20 , therefore, the Committee urged the enactment of laws specifically entumerating rights such as "the right not to be deprived of property by a public officer except by due process of law; the right to be free from personal injury inflicted by a public officer; the right to engage in a lawful activity without interference by a public officer; and the right to be free from discriminatory law enforcement resulting from either active or passive conduct by a public officer."st

Behind this recommendation lie the implications of the Screzes decision. Directly responsible for the narrow interpretation of "wilfulness" in that case, the lack of enumeration in Section 20 poses a threat to future prosecutions under the Section. ${ }^{88}$ The necessity of proving a "specific intent" militates

81. Section 19 has already been given a content, lacking in Section 20 , by numerous cases and statutes. See discussion, pp. 859-60 supra. Further enumeration would be superfluous where the courts have already recognized the rights enumerated; and, since fcderal authority over private offenses is limited, would be of dubious constitutional validity where those rights have not yet received judicial approval.

82. An amendment has already been introduced to make this change. $H . R .4471$, 80th Cong., 1st Sess. (1947).

83. Crv. RTS. REP., supra note 1, at 156.

84. Ibid.

85. In adhering to the United Nations Charter, the United States pledged itself to "promote respect for, and observance of, human rights and fundamental freedoms for all." ART. 55(c), United Nations Charter, 59 Stat. 1031 (1945). Since treaties are the "supreme law of the land," U.S. Const., Art. VI, and since Congress has the power to define and punish offenses against the law of nations, U.S. Const., Art. I, $\$ 8(10)$, Congress may have, under the Charter, power to protect minorities not vested by the Constitution itself. Cf. Missouri v. Holland, 252 U.S. 416, 433 (1920).

86. See note 81 supra. Section 20 figured in only two reported cases before 1939. See note 32 supra.

87. CIv. RTS. REP., supra note 1, at 157.

88. See discussion p. 862 supra. 
against statement of the offense itself in general terms. Consequently, although the present statute indicates an intention to protect against public officers any right or privilege under the Constitution, the enumeration of specific offenses would serve a not unnecessary purpose in furnishing concrete standards of "wilfulness." 89 In addition, enumeration could point the way for courts to effectuate, consistent with the Constitution, the full intent of Congress.90

Further legislation supplementing both general and special statutes has been proposed. As enumeration extends the range of federal protection, however, constitutional questions increasingly intrude. 1 Certainly there is no problem in strengthening the Peonage and Slave Kidnapping Acts; $;^{92}$ the plenary powers reserved to Congress under the Thirteenth Amendment could be utilized in legislation precisely defining not only peonage but other forms of involuntary servitude as well. ${ }^{93}$ But the pending Case Bill, ${ }^{03}$ declaring a federal "right to be free from lynching," may indeed challenge traditional concepts of constitutional interpretation. ${ }^{95}$ The Bill provides penalties for

89. Since offenses under Section 19 have in effect been enumerated by various court decisions, the barrier to successful prosecution under Section 20 erected by the Screws decision is not as likely to cause difficulty in the prosecution of private offenses.

90. It has been suggested that enumeration may present an additional problem: If the offense is not entmerated, does the doctrine of expressio usuius est exclusio alteritus apply to mean that the offense is not punishable? See Fraenkel, The Fcderol Civil Rights Lawe, 31 IIINN. L. REv. 301, 326 (1947). The difficulty could be obviated, however, by language preceding the enumeration such as "including but not limited to," and careful explanation of the bill by its sponsors.

91. Thus, the recommended enumeration, under Section 20, of a specific right "to be free from discriminatory law enforcement resulting from either active or passive conduct by a public officer" might raise a constitutional issue. See discussion p. 871 infra.

92. See notes 59,63 sipra.

93. See cases cited notes $61,62,64$ supra.

94. H. R. 5673, 80th Cong., 1st Sess. (1947).

95. The right to be free from lynching was held to be a federal right in Ex farlc Riggins, 134 Fed. 404 (C.C.N.D. Ala. 1904), under the statute from which the present Section 19 was reenacted, REv. STAT. $\$ 550$ (1875), on the ground that the Fourteenth Amendment authorized Congress both to prevent positive state action against federal rights, and "to aid the state" in performing its duty to guarantee due process of law by" removing resistance thereto by private violence.

But this decision was in effect overruled by the same court in United States v. Powell, 151 Fed. 648 (C.C.N.D. Ala. 1907), by construing Hodges v. United States, 203 U.S. 1 (1906), decided subsequent to the Riggins case, "as a binding authority that no right, privilege, or immunity in respect of due process, at any stage in the duty of affording it, arises under the Fourteenth Amendment, unless there be denial of the right by the state or its officers, and that no immunity whatever is secured under the Constitution or laws ... against lawlessness of private individuals which frustrates the state's efforts to perform its constitutional duty, although thereby all enjoyment of the benefits of due process be prevented." Id. at 664. The Powell case was affirmed without opinion by the Supreme Court, 212 U.S. 564 (1909).

And see Recent Statutes, The Federal Anti-Lynching Bill, 38 Cor. L. Rw. 199 
private individuals who participate in a conspiracy to invade that right or who instigate or aid in a lynching; and for public officers from whose neglect or wilful failure to act lynching results or is allowed to go unpunished.00 In addition, the Bill makes the governmental subdivision within which such deprivations occur financially responsible to the victim or his survivors. ${ }^{07}$ Backed by a firm statement of Congressional intent based on specific findings, ${ }^{08}$ the proposed statute may perhaps be reminiscent of the Commerce Clause legislation which induced the new Court to sanction the exercise by Congress of "an affirmative power commensurate with the national needs." If lynching is a national problem, it too should be capable of solution through powers entrusted to Congress under the federal system. But solution requires a reappraisal of current theory by the courts themselves.

\section{Judicial Interpretation}

One approach to the problem is suggested in the series of cases arising under Section 19. The dictum in the Powe case that there is a federal right to discuss the national "government, its elections, its laws, its operations, and its officers"100 affords a significant rationale for bringing many forms of private violence within the reach of the express and implied powers entrusted to Congress by the Constitution. Whether these powers have been exercised solely by the enactment of Section 19 , or whether they have been exercised in particular legislation,--such as the recent National Labor Relations Act, the Social Security Act, the Wages and Hours Act, the Lanham Act (housing), and the Selective Service Act (veterans' reemployment),-the courts clearly have a basis for enlarging the category of rights federally secured against private encroachment. The technique suggested by the Powe opinion, however, is capable of only limited application. If carried to the extremes advanced by some proponents of anti-lynching legislation, ${ }^{101}$ it would permit the federal

(1938): "That Congress could not under the Fourteenth Amendment make lynching itsclf a Federal crime is perfectly clear. ..." Id. at 200.

96. Members of lynch mobs or individuals inciting or aiding a lynching would bo fined up to $\$ 10,000$, or imprisoned up to twenty years, or both. Public officials guilty of wilful neglect would be fined up to $\$ 5,000$, or imprisoned up to five years, or both. $H$. $R$. 5673, 80th Cong., 1st Sess. $\S \S 3,4$ (1947).

97. Subdivisions where lynchings occur would be liable to the victim of the lynching or the next of kin for not less than $\$ 2,000$ or more than $\$ 10,000$. The subdivision would be permitted, as an affirmative defense, to show by a preponderance of evidence that its public officers used all diligence to protect the victim. Id. $\$ 6$.

98. Id. \&1.

99. North American Co. v. S.E.C., 327 U.S. 686, 705-6, 710-1 (1946).

100. Powe v. United States, 109 F.2d 147, 151 (C.C.A. 5th 1940).

101. A former chief of the Civil Rights Section of the Department of Justice has found a federal right "not to be lynched" implicit in the Fourteenth Amendment. Rotnem, The Federal Civil Right "Not To Be Lynched", 28 WAsr. U. L. Q. 57 (1943) : "A person tried in the state courts has a theoretical right to have the state court's determination reviewed in the light of the due process clause under the federal judicial power. . . . To 
government to prosecute any act of private violence. Such an extension of principle proves too much. If federal power can be extended so far, then the fact of a federal system is destroyed while only the form remains.

A solution less far-reaching in its implications may perhaps come from the line of decisions defining, under Section 20, the bounds of federal action against state aggression. For the Fourteenth Amendment provides direct federal surveillance over the actions of the states themselves, in order to underline, rather than to undermine, their primary responsibility for individual safety. Thus, it may be forcefully argued that states are as much responsible for sins of omission as of commission. ${ }^{102}$ When it can be shown that local authorities, aware of the probable occurrence of violence, have refused protection to the victim, prosecution should be feasible on the basis of Section 20 alone. If authorities have, over a period of time, unequally applied state criminal statutes, or have wilfully neglected, in a single instance, to prosecute the authors of private violence, it may also be possible through the penalties of Section 20 to remind them of their responsibility. In either case, the passage of supplementary legislation categorizing these particular derelictions as federal offenses should not encounter serious constitutional objections.

But the inaction of state officers is only a part of a lynching neither prevented nor punished. May not a lynch mob itself be recognized, under these

deprive a person of the opportunity for a reviewable trial, then, is to deprive him of a right that is not only secured to him by the Federal Constitution but enforceable and enforced in the federal courts,-in brief, it is to interfere with the administration of federal justice, in this sense, itself." Id. at 68. Cf. note 95 supro.

A constitutional basis is also sought in the clause guaranteeing each state "a republican form of government," U.S. CoNsr., Art. IV, $\$ 4$; in the Commerce Clause, in that lynching is essentially an economic problem, U.S. Coxss., Art. I, $\$ 8(3)$; in aid of the power to make treaties and to define and punish offenses against the law of nations, in connection with the United Nations Charter, see note 85 sipra; and by analogies to the Lindbergh Anti-Kidnapping Act, 48 StAr. 781 (1934), 18 U.S.C. $\$ 408_{3}$ (1940), and National Stolen Property Act, 48 Stat. 794 (1934), 18 U.S.C. $\$ 413$ (1940). See $8 f_{3}-$ jority Report, H. R. REP. No. 1597, 80th Cong., 2d Sess. 4-7 (1948); Statement of American Civil Liberties Union and American Jewish Congress, Hearings before Subcommittee No. 4 of the Committee on the Judiciary on H.R. 5673, 80th Cong., $2 \mathrm{~d}$ Sess. 99, 111 (1948). Constitutional Basis for Federal Anti-Lynehing Legislation, 6 Law. Gumb Rev. 643 (1946).

See generally: Recent Statutes, The Federal Anti-Lynching Bill, 38 CoL L REv. 199 (1938); Note, The Consfitutionality of the Wagner-Costigan Anti-Lynching Bill, 2 Geo. Wash. L. Rev. 498 (1934); Dyer, The Constitutionality of a Fcderal AntiLynching Bill, 13 ST. Lours L. REv. 186 (1928). For impassioned presentations of the opposite viewpoint, see Minority Report, H. R. REP. No. 1597, 80th Cong., 2d Sess. 9 (1948), and Hemphill and Woodward, Constitutionality of the Proposed AntiLynching Bill, 2 UnTr. of So. CAR. SeldeN Soc. YeAr BR. 12 (1933). See also Kowvitz, op. cit. supra note 5, at 746; Walter, Proposals for a Fcderol Anti-Lywiching Law, 28 AMr. PoL. Sct. Rev. 436 (1934).

102. That state inaction, i.e., wilful failure to protect persons from violence, is equivalent to state action, was recognized in the recent Circuit Court of Appeals case of Catlette v. United States, 132 F.2d 902 (C.C.A. 4th 1943), although doubts were there suggested 
circumstances, as an organ of the state ?103 Since the Civil Rights Cases, interpretation of the Fourteenth Amendment has progressively departed from an inquiry focused on the agency formally clothed with power ${ }^{104}$ and has approached instead a search for the agency effectively exercising power. ${ }^{105} \mathrm{~A}$ lawless sheriff can only with difficulty be held up as the legal representative of a sovereign state, but he must be recognized as the source of governmental power in his own bailiwick.100 A political party has been held to differ significantly from a gentlemen's club, ${ }^{107}$ a thoroughfare in a company town is something more than a private right of way, ${ }^{108}$ and a labor union may acquire a measure of responsibility proportionate to its exercise of economic sover-

whether inaction alone would support the imposition of criminal liability. A lower federal court so held in 1874: “. . if the outrages and crimes shown to have been committed in the case before you were well known to the community at large, and that community and the officers of the law wilfully failed to employ the means provided by law to ferret out and bring to trial the offenders, because of the victim being colored, it is a depriving them of the equal protection of the laws." Krekel, J., charging the jury in United States v. Blackburn, 24 Fed. Cas. 1158, 1159, No. 14603 (W.D. Mo. 1874).

103. Majority Report, H. R. REP. No. 1597, 80th Cong., 2d Sess. 5 (1948). See Hale, Force and the State: A Comparison of "Political" and "Economic" Compulsion, 35 CoL. L. REv. 149 (1935): "'The State' ... is thought to have a monopoly of ... political power. Those who wield this official power we have subjected to ... constitutional limitations. Yet much of this recognized political power is not different ... from much of the power that some individuals and private groups can lawfully exercise against other individuals." Id. at 149 . "... the courts have been blind to the fact that much of the private power over others is in fact delegated by the state, and that all of it is 'sanctioned' in the sense of being permitted . . . [T] ... might have recognized the applicability of the Fourteenth Amendment to private cxertions of power. . . ." Id. at 199. See also Lasswell and McDougal, Legal Education and Public Policy: Professional Training in the Public Interest, 52 YArE L. J. 203 (1943): "... the identity of the institutions that exert power can only be determincd by proper investigation, and must not be taken for granted through verbal coincidence." Id. at 219. Cf. Kelsen, Law and Justice in the Pure Theory of Law, 57 YALE L. J. 377, 380-1 (1948).

104. The provisions of the Fourteenth Amendment refer ". . . to actions of the political body denominated a State, by whatever instruments or in whatever modes that action may take. . . A State acts by its legislative, its executive, or its judicial authorities. It can act in no other way." Ex parte Virginia, 100 U.S. 339, 346 (1879). See also Civil Rights Cases, 109 U.S. 3, 13 (1883) ; United States v. Harris, 106 U.S. 629, 639 (1882); United States v. Cruikshank, 92 U.S. 542, 554 (1875); Virginia v. Rives, 100 U.S. 313, 318 (1879).

105. See generally, Note, Applicability of the Fourteenth Amendment to Private Organizations, 61 HARv. L. Rev. 344 (1948); Barnett, What is "State" Action under The Fourteenth, Fifteenth, and Nineteenth Amcidments of the Constitution?, 24 Ore. L. REv. 227 (1945) ; Comment, Race Discrimination in Housing, 57 Y ALE L. J. 426, 433 ff. (1948); Konvitz, op. cit. sipra note 5, at 77-9; 3 Willovguby, Constrututional LAw in the UNTted States 1934-35 (2d ed. 1929); Department of Justice Circular No. 3356, Supp. 1, 20-1, (1940).

106. Screws v. United States, 325 U.S. 91 (1945).

107. Smith v. Allwright, 321 U.S. 649, 663 (1944) ; Elmore v. Rice, 72 F. Supp. 516 (D.S.C. 1947).

108. Marsh v. Alabama, 326 U.S. 501 (1946). 
eignty. ${ }^{109}$ A lynching may more than coincidentally be characterized by state inaction. At least for its purposes, a lynch mob displaces formal state authority. Through tacit ratification, the displacement can become permanent. Whether lynching is today a national problem remains to be settled on the basis of evidence not here examined. But Congressional enactment of the Case Bill would carry a strong presumption in the affirmative. And the solution should be capable of accommodation in the federal system contemplated by the Constitution.

109. Betts v. Easley, 161 Kan. 459, 169 P.2d 831 (1946); 56 YALE L. J. 731 (1947). Mr. Justice Murphy, concurring in Steele v, Louisville and Nashville R.R., 323 U.S. 193, 208 (1944). 